\title{
Growth and Evapotranspiration Response of Two Turfgrass Species to Nitrogen and Trinexapac-ethyl
}

\author{
Benjamin Wherley and Thomas R. Sinclair ${ }^{1}$ \\ Department of Agronomy, University of Florida, Agronomy-Physiology \\ Laboratory, IFAS Building 350, P.O. Box 110965, 2005 SW 23 Street, \\ Gainesville, FL 32611-0965
}

Additional index words. trinexapac-ethyl, PGRs, nitrogen, evapotranspiration, bermudagrass, bentgrass

\begin{abstract}
Resolution of the effects of trinexapac-ethyl and nitrogen (N) application rate on evapotranspiration of low-cut, prostrate turfgrass species such as creeping bentgrass (Agrostis stolonifera L.) and hybrid bermudagrass [Cynodon dactylon (L.) Pers. $\times$ Cynodon transvaalensis Burtt-Davy] has not been explored. This study sought to examine the integrated growth and evapotranspiration responses of these two turfgrass species to two $\mathrm{N}$ rates and application of trinexapac-ethyl, a commonly used growth-regulating compound for suppressing turfgrass shoot growth. 'Penncross' creeping bentgrass and 'Tifdwarf' bermudagrass were studied. We hypothesized that application of trinexapacethyl and/or lower $\mathrm{N}$ application rates might result in lower rates of turfgrass evapotranspiration. Two greenhouse studies were conducted over 6-week periods in 2008. A completely randomized design was used to support a two species $\times$ two $\mathrm{N}$ rate $\times$ two trinexapac-ethyl rate factorial. Shoot and root growth and evapotranspiration were determined from the two grass species when maintained in well-watered conditions and grown in pots. The treatments were either a high $\mathrm{N}\left(1.2 \mathrm{~g} \mathrm{~N} / \mathrm{m}^{2} /\right.$ week) or a low $\mathrm{N}(0.3 \mathrm{~g} \mathrm{~N} /$ $\mathrm{m}^{2} /$ week) application and either 0 or $28 \mathrm{mg} \cdot \mathrm{m}^{-2}$ a.i. trinexapac-ethyl. Application of trinexapac-ethyl and use of the low $\mathrm{N}$ rate each significantly reduced shoot growth in both species; however, neither factor caused a reduction in turfgrass water use. The high $\mathrm{N}$ rate promoted increased root growth in both species during the spring, but there was no effect of either factor on rooting during the summer study. These results indicate that although decreasing $N$ application rates and applying trinexapac-ethyl effectively suppress shoot growth, neither is likely to have any impact on overall water requirements for these species when maintained in well-watered conditions.
\end{abstract}

Nitrogen (N) is the nutrient used in greatest quantity by plants and, consequently, is the element around which most turfgrass fertility programs are centered. Nitrogen is a component of many of the biochemical constituents of plants, including chlorophyll, amino acids, proteins, enzymes, vitamins, and many other materials critical to their function (Christians, 1998). When conditions are favorable, $\mathrm{N}$ applications to turfgrass result in stimulated shoot growth. It has been reported in some previous studies that turfgrass evapotranspiration rates increase with increasing $\mathrm{N}$ fertilization, a relationship often attributed to changes in leaf elongation rate and/or the amount of transpiring leaf area exposed to the atmosphere between mowings (Ebdon et al., 1999; Feldhake et al., 1983; Green et al., 1990; Krogman, 1966; Mantell, 1966; Shearman and Beard, 1973). The grass species used in these previous studies have usually been mowed on a weekly basis at heights exceeding $25 \mathrm{~mm}$.

Received for publication 11 Mar. 2009. Accepted for publication 18 Apr. 2009.

${ }^{1}$ To whom reprint requests should be addressed; e-mail trsinc@ufl.edu.
One approach to counter high evapotranspiration rates of well-growing, highly maintained turfgrass may be the application trinexapac-ethyl (TE), a plant growth regulator (Watschke et al., 1992). TE interferes with gibberellin biosynthesis and reduces laminar cell elongation, thereby decreasing the need for frequent mowing (Adams et al., 1992). Also, TE application induces production of shorter, thicker cells (Ervin and Koski, 2001b), increased specific leaf weight (Gaussoin et al., 1997; Heckman et al., 2001), increased tillering (Beasely et al., 2005; Ervin and Koski, 1998; Fagerness and Yelverton, 2000; Goss et al., 2002), and changes in total root length and surface area (Beasely et al., 2005). By decreasing canopy height through suppression of vertical shoot elongation, one consequence may be a decrease in evapotranspiration rates. TE is reportedly capable of reducing turfgrass water use by up to $25 \%$ (Syngenta Professional Products, 2008).

Although there have been some previous studies concerning the influence of TE on turfgrass evapotranspiration rates, these have mainly involved higher-cut, upright-growing grass species. Furthermore, results have been somewhat contradictory. TE applications were found to decrease evapotranspiration rates by $11 \%$ in a 6 -week greenhouse study with tall fescue (Festuca arundinacea Schreb.) (Marcum and Jiang, 1997) and by $20 \%$ in a mixed stand of kentucky bluegrass (Poa pratensis L.) and tall fescue (King et al., 1997). However, when averaging an entire 3-year field study, Ervin and Koski (2001a) determined that TE applications (applied every 6 weeks) were ineffective at decreasing kentucky bluegrass evapotranspiration rates, only reducing evapotranspiration on 5 of the 34 weeks of the study. Furthermore, correlation analysis did not show any relationship between clipping dry weight and evapotranspiration rates.

More recently, pretreatment with TE (applied $14 \mathrm{~d}$ before imposition of stress) was found to enhance quality of creeping bentgrass during combined drought and heat stress (McCann and Huang, 2007). However, the effects of TE on evapotranspiration in the study were not clear. Although TE-treated and nontreated turf had similar rates of evapotranspiration under nonstressed conditions, TE-treated plants had lower evapotranspiration rates $10 \mathrm{~d}$ after imposition of drought and heat stress $(24 \mathrm{~d}$ after TE application) but higher evapotranspiration rates $11 \mathrm{~d}$ later ( $35 \mathrm{~d}$ after TE application). The timing of TE pretreatment and associated postsuppression rebound growth effects (which often occur 4 to 6 weeks after application) likely coincided with the stress period in the study, making it difficult to sort out the actual effects of TE.

Resolution of the effects of $\mathrm{N}$ rate and TE on evapotranspiration rates of prostrate grass species, specifically creeping bentgrass and bermudagrass, maintained at lower heights of cut (less than $10 \mathrm{~mm}$ ) has not been explored. The height and growth habit of a turfgrass may confound the influence of these cultural factors on evapotranspiration because lateralgrowing, prostrate species are not exposed to as turbulent airflow as might be experienced by grasses with a more upright growth habit such as tall fescue and kentucky bluegrass (Huang, 2008; Kim, 1983). As a result of their prostrate growth pattern, these species may not benefit as greatly from cultural factors aimed at reducing vertical leaf elongation. The objective of this study was to investigate the individual and interactive effects of TE application and $\mathrm{N}$ rate on growth and evapotranspiration of 'Penncross' creeping bentgrass (Agrostis stolonifera L.) and 'Tifdwarf' bermudagrass [Cynodon dactylon (L.) Pers. $\times$ Cynodon transvaalensis BurttDavy].

\section{Materials and Methods}

Spring and summer experiments were conducted over 6-week periods during 2008 in a greenhouse at the University of Florida, Gainesville, FL. A completely randomized design was used to support a two species $\times$ two $\mathrm{N}$ rate $\times$ two TE rate factorial experiment. Twelve pots were constructed for each grass species from $10-\mathrm{cm}$ diameter polyvinyl chloride piping cut into $20-\mathrm{cm}$ lengths. A 
hole was drilled in the bottom end cap of the pot to allow water drainage. A mesh screen was placed in the bottom of each pot and the pot was filled with a soil media of $85: 15(\mathrm{v}: \mathrm{v})$ mixture of medium-textured silica sand and sphagnum peatmoss packed to a final bulk density of $1.5 \mathrm{~g} \cdot \mathrm{cm}^{-3}$. The pot was filled with the soil media to within $2.5 \mathrm{~cm}$ of the top to allow planting of a $2.5-\mathrm{cm}$ depth sod plug so that the base of the turf canopy was level with the top edge of the pot. The grass plugs were obtained using a 10-cm diameter golf cup cutter. Bermudagrass sod plugs were taken from a 5-year-old, native sand-based research green at the University of Florida G. C. Horn Memorial Turfgrass Research Field Laboratory, Citra, FL. Bentgrass sod plugs were removed from $10-\mathrm{cm}$ deep trays of sandbased sod, which was established from seed 8 weeks before each experiment in the greenhouse. During the first 2 weeks of establishment in pots, the grasses received two liquid applications (40 mL each) of fullstrength Hoagland's \#1 culture solution (Hoagland and Snyder, 1933). The solution contained $210 \mathrm{mg} \cdot \mathrm{L}^{-1} \mathrm{~N}, 31 \mathrm{mg} \cdot \mathrm{L}^{-1}$ phosphorus, $235 \mathrm{mg} \cdot \mathrm{L}^{-1}$ potassium, $281 \mathrm{mg} \cdot \mathrm{L}^{-1}$ calcium, $49 \mathrm{mg} \cdot \mathrm{L}^{-1}$ magnesium, $64 \mathrm{mg} \cdot \mathrm{L}^{-1}$ sulfur, $0.1 \mathrm{mg} \cdot \mathrm{L}^{-1}$ boron, $0.01 \mathrm{mg} \cdot \mathrm{L}^{-1}$ copper, $0.5 \mathrm{mg} \cdot \mathrm{L}^{-1}$ iron, $0.1 \mathrm{mg} \cdot \mathrm{L}^{-1}$ manganese, 0.02 $\mathrm{mg} \cdot \mathrm{L}^{-1}$ molybdenum, and $0.01 \mathrm{mg} \cdot \mathrm{L}^{-1}$ zinc. Grasses were also kept well-watered and clipped to $8 \mathrm{~mm}$ (two times per week) for the first 2 weeks using scissors and a ruler.

At the end of the second week of establishment, two $\mathrm{N}$ treatments and two TE treatments were imposed in all combinations (high N/+TE, high N/-TE, low N/+TE, low $\mathrm{N} / \mathrm{TE}$ ) on both species so there were three replicate pots for each treatment. The $\mathrm{N}$ treatments consisted of applying weekly $40 \mathrm{~mL}$ of the previously mentioned nutrient solution containing either a high $(263 \mathrm{mg}$ $\mathrm{N} / \mathrm{L}$ ) or a low $\mathrm{N}$ concentration $(61 \mathrm{mg} \mathrm{N} / \mathrm{L})$. This is equivalent to high and low $\mathrm{N}$ application rates of $1.3 \mathrm{~g} \mathrm{~N} / \mathrm{m}^{2} /$ week and $0.3 \mathrm{~g} \mathrm{~N} /$ $\mathrm{m}^{2} /$ week, respectively. The $\mathrm{N}$ concentration in this nutrient solution was based on the amount of $\mathrm{Ca}\left(\mathrm{NO}_{3}\right)_{2} \cdot 4 \mathrm{H}_{2} \mathrm{O}$ added to the solution, so that all other nutrients were supplied at adequate levels. In addition to the weekly addition of nutrient solution, water was also added between solution applications to ensure that all plants were in a well-watered condition. TE (Primo Maxx; Syngenta Crop Protection, Greensboro, NC) was applied to half the plants in each $\mathrm{N}$ treatment only at the beginning of the experiment. Application of the TE treatments was done using a $\mathrm{CO}_{2}$-powered backpack sprayer calibrated to deliver $28 \mathrm{mg} \cdot \mathrm{m}^{-2}$ a.i. in 81.5 $\mathrm{mL}$ of $\mathrm{H}_{2} \mathrm{O} \mathrm{m}^{2}$.

The effects of the $\mathrm{N}$ and TE treatments on shoot growth and evapotranspiration are reported for two 5-week periods, 26 Feb. through 1 Apr. (spring study) and 25 June through 30 July 2008 (summer study). During both studies, the greenhouse was maintained at $28 / 22{ }^{\circ} \mathrm{C}$ (day/night). Although these temperatures are somewhat above optimal for creeping bentgrass, they are within the lower ideal range for bermudagrass growth (Christians, 1998). In prior studies, we found that both species grew well at these temperatures and therefore felt they would provide the best temperature for conducting a side-by-side study using the two species. The greenhouse caused a $30 \%$ reduction of photosynthetic photon flux $(P P F)$ during both experiments.

Based on the clipping harvests, suppression of shoot growth by TE application lasted 5 weeks after treatment with a postsuppression rebound (growth of TE-treated plants surpassing that of controls) occurring in some treatments on Week 6 of both studies. Because our objective was to measure water use of plants while under TE control, only shoot growth and evapotranspiration data from Weeks 1 through 5 after application were included in the analysis of evapotranspiration and clipping data.

Each week of both studies, turfgrass evapotranspiration was measured gravimetrically from well-watered plants over a 48- or $72-h$ period. Mass was determined by weighing pots at the beginning and end of this period on a balance with a resolution of $0.1 \mathrm{~g}$ (Model SI-8001; Denver Instrument, Denver, $\mathrm{CO})$. Drainage holes in lysimeter bottoms were closed off between weighing events to prevent drainage. Grasses were clipped twice weekly to $8 \mathrm{~mm}$ using scissors and a ruler with clippings collected and oven-dried for $72 \mathrm{~h}$ at $65^{\circ} \mathrm{C}$ before weighing. The two sets of clippings collected each week were combined to provide a weekly indication of shoot growth.

At the completion of each experiment, roots were clipped from the base of the originally established sod plug, separated from soil by rinsing, and dried for $72 \mathrm{~h}$ at $65^{\circ} \mathrm{C}$. Root dry weights were then obtained to determine the effects of the treatments on root growth.

The data were analyzed using the general linear models procedure of SAS (SAS 9.1, Cary, NC). Season $\times$ treatment effect interactions were significant so experiments were analyzed separately. Tukey's test $(P=$
0.05 ) was used to make multiple comparisons between treatment means.

\section{Results and Discussion}

The objective of this research was to investigate the effects of TE application and $\mathrm{N}$ rate on growth and evapotranspiration of 'Penncross' creeping bentgrass (Agrostis stolonifera L.) and 'Tifdwarf' bermudagrass [Cynodon dactylon (L.) Pers. $\times$ Cynodon transvaalensis Burtt-Davy]. Although the effects of $\mathrm{N}$ rate and TE on turfgrass growth have been documented in a number of turfgrass species, there continues to be a lack of data concerning their effects on turfgrass water use, particularly in these two species. Increased turfgrass evapotranspiration associated with high $\mathrm{N}$ application rates has been previously reported, although data have been from studies using less frequently cut turfgrasses that were maintained at $25 \mathrm{~mm}$ or higher (Ebdon et al., 1999; Shearman and Beard, 1973). Our results provide new information on the effects of TE and $\mathrm{N}$ rates on evapotranspiration of prostrate-growing species maintained at lower heights of cut $(8 \mathrm{~mm})$ and therefore may be of greater relevance than past research to golf turf management.

Turfgrass quality was not evaluated directly in this study. However, visual observations indicated no deleterious effects were caused by TE application, because all $\mathrm{N}$ and TE treatment combinations promoted consistently good quality for the duration of each experiment. TE application generally had a positive effect on quality by promoting darker green color at both $\mathrm{N}$ rates.

Shoot growth. TE has been previously shown to suppress turfgrass growth for 4 to 5 weeks under normal field conditions across a variety of turfgrass species (Daniels and Sugden, 1996; Fagerness and Yelverton, 2000; Gardner and Wherley, 2005). Shoot growth in our study, as measured by weekly clipping yields, was noticeably reduced by TE application in both species during both studies (Table 1). Clipping yield reductions of up to $70 \%$ were observed in each species

Table 1. Analysis of variance table for species, trinexapac-ethyl (TE), and nitrogen application rate effects on turfgrass clipping yields, evapotranspiration (ET), and final root dry weight.

\begin{tabular}{|c|c|c|c|c|c|c|}
\hline & \multicolumn{6}{|c|}{$P$ values } \\
\hline & \multicolumn{3}{|c|}{ Spring study } & \multicolumn{3}{|c|}{ Summer study } \\
\hline & Clippings & ET & Root dry wt. & Clippings & ET & Root dry wt \\
\hline$\overline{\text { Species (S) }}$ & $*$ & NS & $* * *$ & NS & $*$ & $* * *$ \\
\hline Trinexapac-ethyl (TE) & $* * *$ & NS & NS & $* * *$ & NS & NS \\
\hline $\mathrm{S} \times \mathrm{TE}$ & NS & NS & NS & NS & NS & NS \\
\hline Nitrogen rate $(\mathrm{N})$ & NS & NS & $* *$ & $*$ & NS & NS \\
\hline $\mathrm{S} \times \mathrm{N}$ & NS & NS & NS & NS & NS & NS \\
\hline $\mathrm{TE} \times \mathrm{N}$ & NS & NS & NS & $*$ & NS & NS \\
\hline $\mathrm{S} \times \mathrm{TE} \times \mathrm{N}$ & NS & NS & NS & NS & NS & NS \\
\hline Week (W) & $* * *$ & $* *$ & & $*$ & NS & \\
\hline $\mathrm{W} \times \mathrm{S}$ & NS & NS & & $*$ & NS & \\
\hline $\mathrm{W} \times \mathrm{TE}$ & NS & NS & & $*$ & NS & \\
\hline $\mathrm{W} \times \mathrm{S} \times \mathrm{TE}$ & NS & NS & & NS & NS & \\
\hline $\mathrm{W} \times \mathrm{N}$ & $* *$ & NS & & NS & NS & \\
\hline $\mathrm{W} \times \mathrm{S} \times \mathrm{N}$ & NS & NS & & $*$ & NS & \\
\hline $\mathrm{W} \times \mathrm{TE} \times \mathrm{N}$ & NS & NS & & $* *$ & NS & \\
\hline $\mathrm{W} \times \mathrm{S} \times \mathrm{TE} \times \mathrm{N}$ & NS & NS & & NS & NS & \\
\hline
\end{tabular}
Ns, * **, ***Nonsignificant or significant at $P=0.05,0.01$, or 0.001 , respectively. 
and generally took place within the initial 2 weeks after application (Figs. 1 and 3 ). During the spring study, creeping bentgrass had higher clipping yields than bermudagrass; however, no differences in clipping yield could be detected between the species during the summer study (Table 1; Fig. 1).

Analysis of variance indicated an interaction between week and nitrogen rate in the spring study (Table 1). With the exception of bermudagrass in Week 2, TE had no effect on clipping yields in either species when applied in combination with the low $\mathrm{N}$ rate (Fig. 1A). However, at the high $\mathrm{N}$ rate, TE reduced creeping bentgrass clippings in Weeks 1 and 2 and bermudagrass clippings during Weeks 2 and 3 (Fig. 1B).

Analysis of variance indicated two threeway interactions during the summer study. An interaction among week, species, and $\mathrm{N}$ rate revealed differences in the response of the two species to $\mathrm{N}$ rate (Fig. 2). Whereas creeping bentgrass produced significantly higher clipping yields at the high $\mathrm{N}$ rate on 3 of the 5 weeks, bermudagrass clipping yields, although greater at the high $\mathrm{N}$ rate 4 of the 5 weeks, were not statistically different from those grown at the low $\mathrm{N}$ rate on any date. Analysis of variance also indicated an interaction among week, $\mathrm{TE}$, and $\mathrm{N}$ rate in the summer study. With the exception of Week 3 , shoot growth was continually suppressed over the 5-week study period by $\mathrm{TE}$ at the low $\mathrm{N}$ rate. However, at the high $\mathrm{N}$ rate, TE suppression lasted only 3 weeks, after which a rebound in shoot growth occurred in plants previously treated with TE (Fig. 3).

Furthermore, the results of the summer study revealed that growth suppression by TE occurred for a longer duration at the low $\mathrm{N}$ rate than the high $\mathrm{N}$ rate (5 versus 3 weeks of suppression, respectively) (Fig. 3), indicating that TE appeared to be more rapidly metabolized at the higher $\mathrm{N}$ rate. This effect was not observed during the spring, suggesting that TE metabolism may be influenced by $\mathrm{N}$ rate and/or day length. We are unaware of any research examining either of these factors on TE metabolism, although previous studies have shown increased TE efficacy when plants are grown at cooler temperatures (Beasely and Branham, 2007; Fagerness et al., 2002; Lickfeldt et al., 2001).

Root growth. In the spring study, both species produced greater root mass at the high $\mathrm{N}$ rate (Table 1; Fig. 4); however, no differences resulting from $\mathrm{N}$ rate were detected in summer (Table 1). TE had no effect on rooting during either study. Differences in root growth were observed between
A

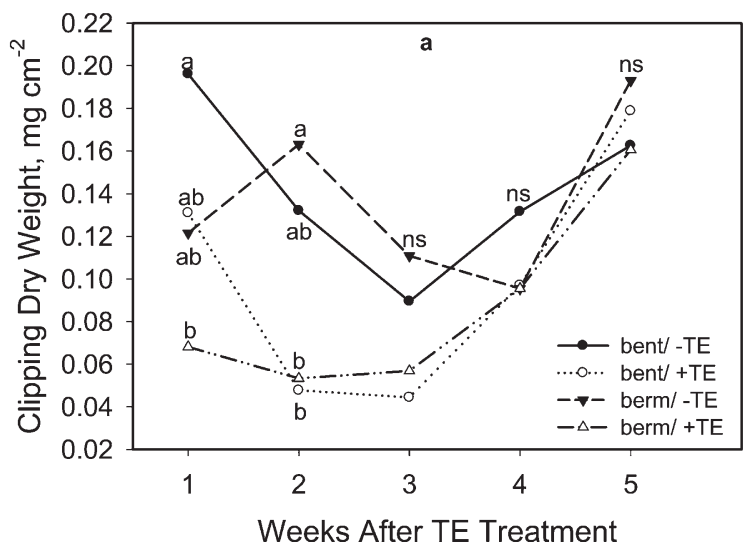

B

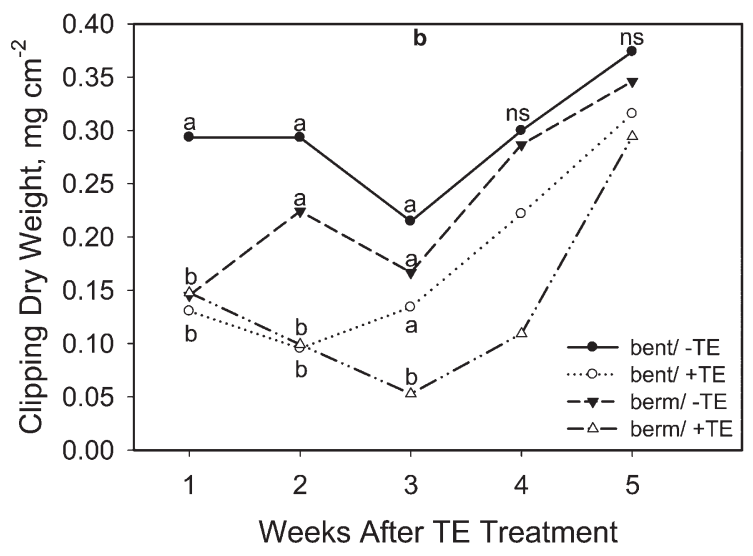

Fig. 1. Change in weekly clipping yield over 5 weeks after application of trinexapac-ethyl (+TE) compared with no growth regulator (-TE) on creeping bentgrass (bent) and bermudagrass (berm) at (A) low and (B) high nitrogen rates during the spring study. Symbols with the same letter on the same date are not statistically different based on Tukey's test at $P=0.05$. species after both studies (Table 1). Root dry weights of creeping bentgrass were nearly four times greater those of bermudagrass after the spring study and approximately three times greater after the summer study (Fig. 4). This was somewhat surprising given that $P P F$ (greenhouse caused $25 \%$ reduction) and daytime greenhouse temperatures $\left(28^{\circ} \mathrm{C}\right)$ were within the lower published range (26.6 to $32.2{ }^{\circ} \mathrm{C}$ ) required for optimal bermudagrass root growth (Lovvorn, 1945). Visual observation during root harvest indicated that both species had, in fact, produced roots extending to the bottoms of pots. Therefore, it appears that the primary factor contributing to this difference was the initial root density of the sod plugs used. Creeping bentgrass sod had been established from seed just 8 weeks before the experiment, whereas the bermudagrass was taken from 5-year-old field plots before the start of the experiment. As such, a noticeably greater density of actively growing fine roots was observed at the base of the creeping bentgrass relative to bermudagrass sod plugs used in the experiment. Furthermore, the decreased growth of bermudagrass roots could have resulted from partitioning to rhizomes within the original $25-\mathrm{cm}$ deep plug, which are not found in creeping bentgrass.

It appears that leaf carbohydrates accumulate during the period of TE inhibition or may be used to fuel other developmental events, including increased tillering, stem growth, and root growth of turfgrasses (Han et al., 2004). Previous reports of the effects of TE on root growth have been contradictory, although increases in rooting from TE are more often associated with warm-season grasses, particularly hybrid bermudagrass. Although effectively suppressing shoot growth, TE failed to influence root growth in either species in this study. This is consistent with previous reports of TE having no effect on root mass of perennial ryegrass seedlings or on root mass of kentucky bluegrass to which TE was applied for 3 years (Ervin and Koski, 1998, 2001a). TE also failed to increase root mass of creeping bentgrass putting green turf when applied monthly for 2 years (Fagerness and Yelverton, 2001). Our results contradict reports of TE applications increasing root mass in 'Tifeagle' bermudagrass (McCullough et al., 2006) and 'Tifway' bermudagrass (Fagerness et al., 2002). When evaluating the root growth data from this study, the relatively short duration of the study periods should be taken into consideration, because it is possible that longer study periods or repeated applications may be required to better detect differences in rooting resulting from TE.

Although TE had no effect on rooting in this study, the high $\mathrm{N}$ rate led to greater root growth by both species in the spring study. This effect is consistent with reports of $\mathrm{N}$ on root mass in the literature, which often show root mass increases from low to moderate $\mathrm{N}$ rates, above which root mass declines. This effect has been shown in both bermudagrass (Pessarakli, 2008) and creeping bentgrass 


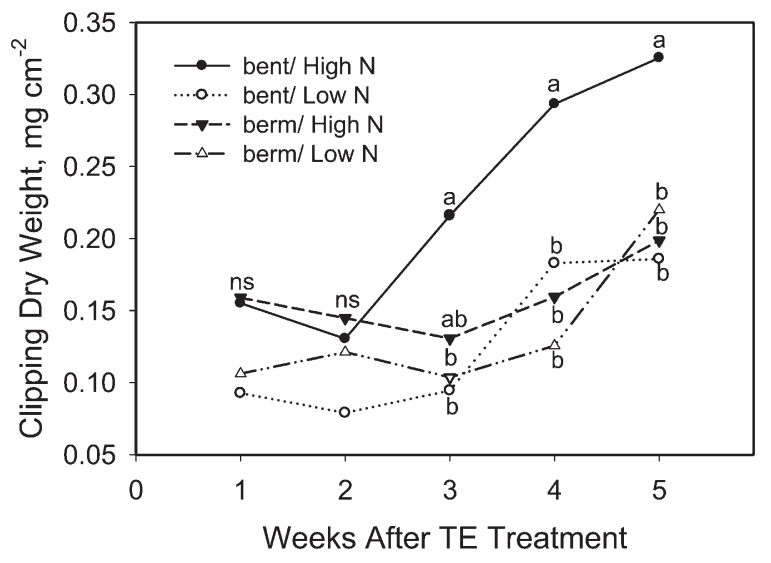

Fig. 2. Change in weekly clipping yield over 5 weeks in creeping bentgrass (bent) and bermudagrass (berm) at high and low nitrogen rates during the summer study. Means are pooled over trinexapac-ethyl rates. Symbols followed by the same letter on the same date are not significantly different based on Tukey's test at $P=0.05$.

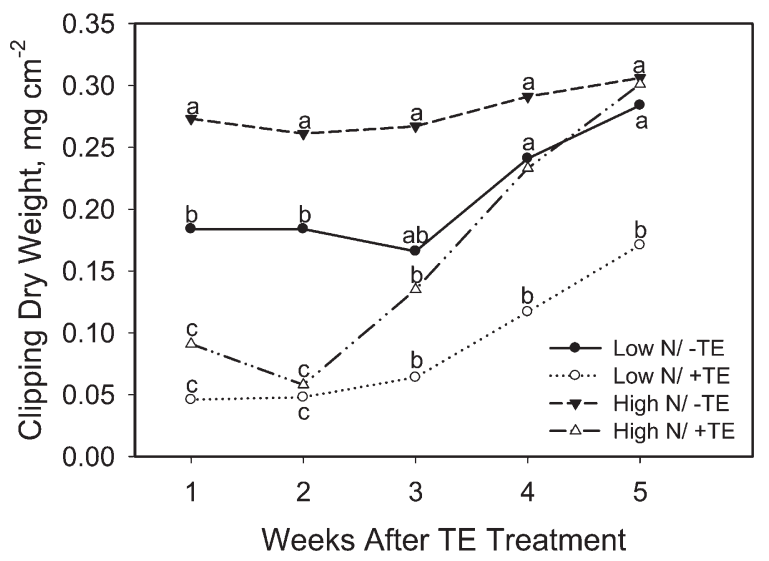

Fig. 3. Change in weekly clipping yield over 5 weeks following application of trinexapac-ethyl (+TE) compared with no growth regulator (-TE) at different weekly nitrogen application rates during the summer study. Means are pooled over species. Symbols followed by the same letter on the same date are not significantly different based on Tukey's test at $P=0.05$.

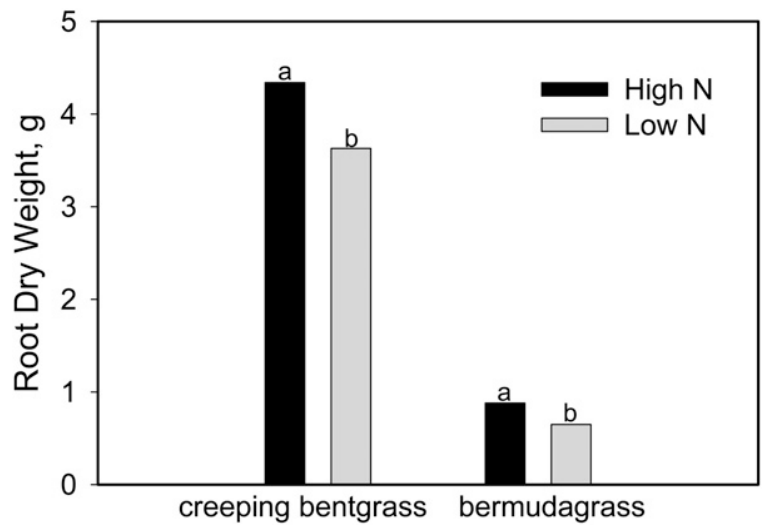

Fig. 4. Final root dry weights after the spring study. Means are pooled over trinexapac-ethyl rates. Letters denote significant differences within each species at $P=0.05$ based on Tukey's test.

(Bell and DeFrance, 1944; Kohlmeier and Eggens, 1983; Schlossberg and Karnok, 2001).

Evapotranspiration. Although TE and N rate affected shoot growth of both species, evapotranspiration rates were not influenced by these factors in either study (Table 1).
Evapotranspiration rates also did not differ between species in the spring, but analysis of variance indicated a species difference during Expt. 2 (Table 1). When averaging overall treatments and weeks of the summer study, creeping bentgrass had mean evapotranspiration rates of $2.32 \pm 0.10 \mathrm{~mm} \cdot \mathrm{d}^{-1}$ and bermudagrass had mean evapotranspiration rates of $2.36 \pm 0.11 \mathrm{~mm} \cdot \mathrm{d}^{-1}$.

Our results show that when TE, and to some extent low $\mathrm{N}$ rates, were applied to both of these turfgrasses, evapotranspiration continued at similar levels to plants receiving no TE or high rates of $\mathrm{N}$. These results contradict reports of TE reducing evapotranspiration in tall fescue and kentucky bluegrass (King et al., 1997; Marcum and Jiang, 1997), but confirm those of Ervin and Koski (2001a) who found that TE-induced shoot growth suppression did not correspond to reduced kentucky bluegrass evapotranspiration in 29 of the 34 weeks of their field study. Ervin and Koski (2001a) suggested that TE-promoted reductions in shoot growth were not substantial enough to reduce leaf area index such that transpiration was reduced. Although TE reduced vertical shoot elongation in our study, it is quite possible that lateral growth of tillers positioned near the soil surface may have remained unchanged or even been promoted by trinexapac-ethyl application; however, this was not detectable through our analysis. This could have offset any TEinduced decrease in leaf area index brought about through reduced vertical leaf growth. TE reportedly has little effect on and may even promote increased tillering of both warm- and cool-season turfgrasses (Ervin and Koski, 1998; Fagerness et al., 2002).

Our results indicate that decreasing $\mathrm{N}$ application rates and applying TE can effectively suppress shoot growth. However, in contrast to previous reports primarily involving taller, more upright-growing turfgrass species, neither factor is likely to have a significant impact on overall water requirements for these species when managed at low mowing heights and in well-watered conditions.

\section{Literature Cited}

Adams, R., E. Kerber, K. Pfister, and E.W. Weiler. 1992. Studies on the action of the new growth retardant CGA 163'935 (cimectacarb), p. 818827. In: Karssen, C.M., L.C. van Loon, and D. Vreugdenhil (eds.). Progress in plant growth regulation. Kluwer Academic Publ., Dordrecht, The Netherlands.

Beasely, J.S. and B.E. Branham. 2007. Trinexapacethyl and paclobutrazol affects kentucky bluegrass single-leaf carbon exchange rates and plant growth. Crop Sci. 47:132-138.

Beasely, J.S., B.E. Branham, and L.M. OrtizRibbing. 2005. Trinexapac-ethyl affects kentucky bluegrass root architecture. HortScience 40:1539-1542.

Bell, R.S. and J.A. DeFrance. 1944. Influence of fertilizers on the accumulation of roots from closely clipped bentgrasses and on the quality of the turf. Soil Sci. 58:17-24.

Christians, N. 1998. Fundamentals of turfgrass management. Sleeping Bear Press, Inc., Chelsea, MI.

Daniels, R.W. and S.K. Sugden. 1996. Opportunities for growth regulation of amenity grass. Pestic. Sci. 47:363-369.

Ebdon, J.S., A.M. Petrovic, and R.A. White. 1999. Interaction of nitrogen, phosphorus, and potassium on ET rate and growth of kentucky bluegrass. Crop Sci. 39:209-218. 
Ervin, E.H. and A.J. Koski. 1998. Growth responses of Lolium perenne L. to trinexapacethyl. HortScience 33:1200-1202.

Ervin, E.H. and A.J. Koski. 2001a. Trinexapacethyl effects on kentucky bluegrass evapotranspiration. Crop Sci. 41:247-250.

Ervin, E.H. and A.J. Koski. 2001b. Trinexapacethyl increases kentucky bluegrass leaf cell density and chlorophyll concentration. HortScience 36:787-789.

Fagerness, M.J. and F.H. Yelverton. 2000. Tissue production and quality of 'Tifway' bermudagrass as affected by seasonal application patterns of trinexapac-ethyl. Crop Sci. 40:493-497.

Fagerness, M.J. and F.H. Yelverton. 2001. Plant growth regulator and mowing height effects on seasonal root growth of 'Penncross' creeping bentgrass. Crop Sci. 41:1901-1905.

Fagerness, M.J., F.H. Yelverton, D.P. Livingstone III, and T.W. Rufty, Jr. 2002. Temperature and trinexapac-ethyl effects on bermudagrass growth, dormancy, and freezing tolerance. Crop Sci. 42:853-858.

Feldhake, C.M., R.E. Danielson, and J.D. Butler. 1983. Turfgrass evapotranspiration. I. Factors influencing rates in urban environments. Agron. J. 75:824-830.

Gardner, D.S. and B.G. Wherley. 2005. Growth response of three turfgrass species to nitrogen and trinexapac-ethyl in shade. HortScience 40:1911-1915.

Gaussoin, R.E., B.E. Brahnam, and J.A. Flore. 1997. Carbon dioxide exchange rate and chlorophyll content of turfgrasses treated with flurprimidol or mefluidide. J. Plant Growth Regul. 16:73-78.

Goss, R.M., J.H. Baird, S.L. Kelm, and R.N. Calhoun. 2002. Trinexapac-ethyl and nitrogen effects on creeping bentgrass grown under reduced light conditions. Crop Sci. 42:472-479.
Green, R.L., K.S. Kim, and J.B. Beard. 1990. Effects of flurprimidol, mefluidide, and soil moisture on St. Augustinegrass evapotranspiration rate. HortScience 25:439-441.

Han, S.W., T.W. Fermanian, J.A. Juvik, and L.A. Spomer. 2004. Total nonstructural carbohydrate storage in creeping bentgrass treated with trinexapac-ethyl. HortScience 39:14611464.

Heckman, N.L., G.L. Horst, and R.E. Gaussoin. 2001. Influence of trinexapac-ethyl on specificleaf weight and chlorophyll content of $\mathrm{Poa}$ pratensis. Intl. Turf Soc. Res. J. 9:287-290.

Hoagland, D.R. and W.C. Snyder. 1933. Nutrition of strawberry plants under controlled conditions. Proc. Amer. Soc. Hort. Sci. 30:288-294.

Huang, B. 2008. Mechanisms and strategies for improving drought resistance in turfgrass. Acta Hort. 783:221-227.

Kim, K.S. 1983. Comparative evapotranspiration rates of thirteen turfgrasses grown under both non-limiting soil moisture and progressive water stress conditions. MS Thesis, Texas A\&M University, College Station, TX. p. 64.

King, R.W., C. Blundell, L.T. Evans, L.N. Mander, and J.T. Wood. 1997. Modified gibberellins retard growth of cool-season turfgrasses. Crop Sci. 37:1878-1883.

Kohlmeier, G.P. and J.L. Eggens. 1983. The influence of wear and nitrogen on creeping bentgrass growth. Can. J. Plant Sci. 63:189-193.

Krogman, K.K. 1966. Evapotranspiration by irrigated grass as related to fertilizer. Can. J. Plant Sci. 47:281-287.

Lickfeldt, D.W., D.S. Gardner, B.E. Branham, and T.B. Voigt. 2001. Implications of repeated trinexapac-ethyl applications on kentucky bluegrass. Agron. J. 93:1164-1168.

Lovvorn, R.L. 1945. The effect of defoliation, soil fertility, temperature and length of day on the growth of some perennial grasses. J. Amer. Soc. Agron. 37:570-582.

Mantell, A. 1966. Effect of irrigation frequency and nitrogen fertilization on growth and water use of kikuyugrass lawn (Pennisetum clandestinum Hochst.). Agron. J. 58:559-561.

Marcum, K.B. and H. Jiang. 1997. Effects of plant growth regulators on tall fescue rooting and water use. J. Turfgrass Manage. 2:13-27.

McCann, S.E. and B. Huang. 2007. Effects of trinexapac-ethyl foliar application on creeping bentgrasses responses to combined drought and heat stress. Crop Sci. 47:2121-2128.

McCullough, P.E., H. Liu, L.B. McCarty, T. Whitwell, and J.E. Toler. 2006. Growth and nutrient partitioning of 'Tifeagle' bermudagrass as influenced by nitrogen and trinexapac-ethyl. HortScience 41:453-458.

Pessarakli, P. 2008. Growth response of bermudagrass to various levels of nutrients in culture medium, p. 57-63. In: Pessarakli, M. (ed.). Handbook of turfgrass management and physiology. CRC Press, Boca Raton, FL.

Schlossberg, M.J. and K.J. Karnok. 2001. Root and shoot performance of three creeping bentgrass cultivars as affected by nitrogen fertility. J. Plant Nutr. 24:535-548.

Shearman, R.C. and J.B. Beard. 1973. Environmental and cultural preconditioning effects on water use rate of Agrostis palustris Huds. cultivar Penncross. Crop Sci. 13:424-427.

Syngenta Professional Products. 2008. Primo MAxx ${ }^{\circledR}$ pgr linked to fuel and labor savings. 2 Sept. 2008. <http://syngentaprofessionalproducts. com/news_releases/news.aspx?id=80783>.

Watschke, T.L., M.G. Prinster, and J.M. Breuninger. 1992. Plant growth regulators and turfgrass management, p. 557-588. In: Waddington, D.V., R.N. Carrow, and R.C. Shearman (eds.). ASA-CSSA-SSSA Turfgrass Agron. Monogr. 32. 